Rol de los arrecifes del poliqueto invasor Ficopomatus enigmaticus Fauvel 1923 (Polychaeta: Serpulidae) en el reclutamiento de Cyrtograpsus angulatus Dana 1851 (Brachyura: Grapsidae), en la laguna costera Mar Chiquita, Argentina

\title{
The role of the invasive polychaete Ficopomatus enigmaticus Fauvel 1923 (Polychaeta: Serpulidae) reefs in the recruitment of Cyrtograpsus angulatus Dana 1851 (Brachyura: Grapsidae), in the Mar Chiquita coastal lagoon, Argentina
}

\author{
Tomás A. Luppi* \\ Claudia C. Bas \\ CONICET \\ Departamento de Biología \\ FCEyN, UNMDP \\ c.c. 1245,7600 Mar del Plata, Argentina \\ *E-mail: taluppi@mdp.edu.ar \\ Recibido en octubre de 2001; aceptado en abril de 2002
}

\section{Resumen}

El poliqueto constructor de arrecifes calcáreos Ficopomatus enigmaticus es considerada una especie invasora en Argentina. Citada para el país en 1943, ha mostrado una importante expansión hasta nuestros días. Las partes vivas de los arrecifes son los refugios más importantes para los reclutas del cangrejo grápsido Cyrtograpsus angulatus en la laguna costera Mar Chiquita, en la Provincia de Buenos Aires, Argentina. En este trabajo se evalua el rol de los arrecifes de F. enigmaticus en el reclutamiento de C. angulatus, mediante la estimación del volumen total de arrecife vivo y el número y biomasa de reclutas y juveniles pequeños que pueden habitar el interior de los arrecifes. El volumen total de arrecife vivo estimado para 1999 fue de $353,849 \mathrm{~m}^{3}$, un $50 \%$ más que el estimado para 1975. El número máximo de cangrejos que pueden contener los arrecifes a lo largo de todo un periodo de reclutamiento fue estimado en $1.68 \times 10^{10}$ individuos, o $1,946 \mathrm{t}$ si son expresados como biomasa. Los resultados, integrados a información previa, muestran que la invasión de $F$. enigmaticus ha tenido un gran impacto en la biología poblacional de C. angulatus, especialmente por el incremento de la disponibilidad de refugios para sus reclutas. Este impacto se extiende a toda la comunidad dado que este cangrejo es considerado una especie clave en la Laguna Mar Chiquita.

Palabras claves: especie invasora, arrecifes de poliquetos, cangrejos grápsidos, reclutamiento.

\begin{abstract}
The calcareous reef building Polychaeta Ficopomatus enigmaticus is considered an invader species in Argentina. First mentioned in 1943, it has shown an important expansion up to date. At present, living parts of reefs are the most important refuge to grapsid crab Cyrtograpsus angulatus juveniles in Mar Chiquita, a brackish coastal lagoon in Buenos Aires Province, Argentina. This work assessed the reef's role in C. angulatus recruitment, by estimating the total volume of living reef and the

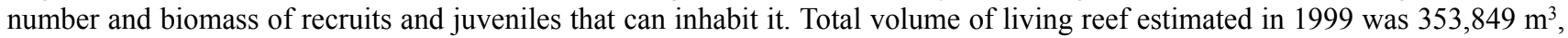
$50 \%$ more than the estimate made in 1975 . The maximum number of juvenile crabs that reefs can host yearly was estimated from the juvenile density in reefs, the number of massive recruitment peaks and the total volume of living reef, in $1.68 \times 10^{10}$, or $1,946 \mathrm{t}$, expressed as biomass. It is shown that the presence of $F$. enigmaticus has a high impact on the populational biology of $C$. angulatus by increasing refuge availability and recruitment success. This impact is extended to the whole community being this crab a key species in the Mar Chiquita Lagoon.
\end{abstract}

Key words: invasive species, Polychaeta reefs, grapsid crab, enhance recruitment.

\section{Introducción}

Las especies invasoras y sus efectos sobre poblaciones y comunidades nativas han interesado a los investigadores por décadas. Este interés, y el aumento del numero de invasiones mediadas por el ser humano, han aumentado nuestro

\section{Introduction}

Invasive species and their effect on native populations and communities have interested researchers for decades. This interest, and the growing number of invasions mediated by human activities, have increased our knowledge about these 
conocimiento sobre estos fenómenos, especialmente en los ambientes terrestres y dulceacúicolas (Mooney y Drake, 1986; Carlton, 1996; Ruíz et al., 1997). Sin embargo, las especies invasoras son cada vez más conspicuas también en los ambientes marinos, especialmente en los estuarios (e.g., Cohen y Carlton (1996) reportaron 230 especies foráneas conocidas en la Bahía de San Fransisco), y el número, variedad y efectos de estas especies continúan en crecimiento. A pesar del incremento en número e importancia de estas especies, los reportes cuantitativos sobre sus impactos son escasos (Ruíz et al., 1999). Los impactos de las especies invasoras en un ambiente estuarial pueden incluir incrementos en la diversidad física, funcional y/o específica y en las relaciones entre los ambientes bentónicos y pelágicos. Tambien pueden afectar la tridimensionalidad del sistema bentónico, aumentar la base alimentaria, incrementar la retención de nutrientes particulados y disueltos, y alterar la diversidad genética tanto dentro como entre las poblaciones (Ruíz et al., 1997; Olenin y Leppäkoski, 1999).

La familia Serpulidae (Polychaeta) incluye muchos géneros de gusanos sedentarios, constructores de tubos calcáreos, que ocupan diversos hábitats, desde marinos a oligohalinos. Algunos géneros de serpulidos son encontrados exclusivamente en ambientes estuariales o hiperhalinos y son formadores de arrecifes verdaderos, de estructura y extensión variable (ten Hove y Weerdenburg, 1978; Bianchi y Morri, 1994). Estos arrecifes son la base de diversos ecosistemas compuestos de organismos incrustantes tales como briozoos, esponjas y bivalvos, y predadores y carroñeros como crustáceos, equinodermos y peces, proveyéndoles sustrato, refugio y/o alimento (ten Hove y van den Hurk, 1993). La abundancia de decápodos en estos ecosistemas puede estar determinada por la abundancia de refugios que provee el arrecife (Heck y Hambrook, 1991; Flores y Negreiros-Fransozo, 1999).

Ficopomatus enigmaticus (Serpulidae) se encuentra tanto en aguas de baja como de alta salinidad (de 5 a 40\%o), incluyendo lagunas de fondos blandos, donde el sustrato duro requerido para el asentamiento es escaso. En los fondos blandos, el arrecife provee su propio sustrato para el asentamiento de sus larvas (ten Hove y van den Hurk, 1993). Este serpúlido es probablemente originario del sureste de Australia, su amplia distribución geografica actual es atribuída a la dispersión pasiva por barcos (Bianchi y Morri, 1994).

Ficopomatus enigmaticus es la especie suspensívora más importante en la comunidad bentónica de la Laguna Mar Chiquita; una laguna costera influenciada por las mareas, localizada al SE de la Provincia de Buenos Aires, Argentina. Construye arrecifes de tubos calcáreos de hasta $0.5 \mathrm{~m}$ de alto y $4 \mathrm{~m}$ de diámetro (Obenat y Pezzani, 1994). Su presencia en la laguna ha sido reconocida recientemente (Orensanz y Estivariz, 1971), y el primer registro para la Argentina es de Necochea, 130 km al sur de Mar Chiquita, en 1943 (Rioja, 1943). En los ultimos años se han realizado intensos estudios sobre el desarrollo temporal de los arrecifes y sus efectos sobre phenomena, particularly in terrestrial and freshwater environments (Mooney and Drake, 1986; Carlton, 1996; Ruíz et al., 1997). Nevertheless, invasive species are increasingly conspicuous in marine communities too, especially in estuaries (e.g., Cohen and Carlton (1996) reported 230 foreign species known at San Francisco Bay), and the number, variety, and effects of these species continue to accrue. Regardless of the increase in number and importance of these species, quantitative records of their impact are scarce (Ruíz et al., 1999). Impact of invasive species in estuarine environments may be represented by an increase of structural diversity, functional and species diversity and bentho-pelagic linkages and thus, the three-dimensionality of the benthic ecosystem, the broadening of the food base, more retention of particulate and dissolved nutrients and alteration of genetic diversity both within and among populations (Ruíz et al., 1997; Olenin and Leppäkoski, 1999).

The family Serpulidae (Polychaeta) includes many genera of sedentary calcareous tube-dwelling worms, inhabiting diverse habitats, from the marine to the oligohaline. Some serpulid genera, found exclusively in brackish and hyperhaline environments, form true reefs of variable structure and size (ten Hove and Weerdenburg, 1978; Bianchi and Morri, 1994). These reefs are the basis of diverse ecosystems composed of incrusting organisms including bryozoans, sponges and bivalves, and motile predators and scavengers like crustaceans, echinoderms and fishes, providing them substrate, refuge and/ or food (ten Hove and van den Hurk, 1993). Decapod abundance in these ecosystems can be determined by the availability of refuges habitat in the reef (Heck and Hambrook, 1991; Flores and Negreiros-Fransozo, 1999).

Ficopomatus enigmaticus (Serpulidae) occurs in water with reduced to high salinities (5 to 40\%), including soft bottom lagoons, where hard substrate required to settle is scarce. In soft bottoms the reef-forming serpulid tubes provide substrate for the settlement of larvae (ten Hove and van den Hurk, 1993). This serpulid probably originated in south east Australia, its large present-day geographical distribution must have developed by way of passive dispersal by ships (Bianchi and Morri, 1994).

Ficopomatus enigmaticus is a suspension feeder in the benthic community at Mar Chiquita; a coastal lagoon influenced by tides, located in the SE Buenos Aires Province, Argentina. It builds 0.5-m-high and 4-m-wide isolated reefs (Obenat and Pezzani, 1994). Its presence seems to be recent (Orensanz and Estivariz, 1971), first recorded in Argentina at Necochea, $130 \mathrm{~km}$ south of Mar Chiquita, in 1943 (Rioja, 1943). In recent years, important studies have been developed about reef growth and their effect on several physical and biological aspects of the Mar Chiquita Lagoon (Schwindt, 2001).

Reefs of $F$. enigmaticus provide habitat for crabs, amphipods, polychaetes, gastropods, bryozoans, diatoms and incrusting green algae (Orensanz and Estivariz, 1971; Obenat and Pezzani, 1989; Schwindt, 2001). This community lives principally at the periphery of the reef, probably because the central zone is made up of dead individuals, and the spaces between 
distintos aspectos físicos y biológicos de la Laguna Mar Chiquita (Schwindt, 2001).

Los arrecifes de $F$. enigmaticus proveen hábitat a cangrejos, anfípodos, poliquetos, gasterópodos, briozoos, diatomeas y algas verdes incrustantes (Orensanz y Estivariz, 1971; Obenat y Pezzani, 1989; Schwindt, 2001). Esta comunidad vive principalmente en la periferia del arrecife, probablemente porque la zona central está caracterizada por la presencia de individuos muertos, y el espacio entre los tubos es ocupado por sedimento (Obenat y Pezzani, 1994). Obenat (datos no publicados) estimó la densidad de poliquetos vivos en tres áreas concéntricas de los arrecifes: anillo externo, media y central. Encontró que el anillo externo, contenía entre el 50 y el $100 \%$ del total de los individuos vivos.

Uno de los componentes más importantes de la macroepifauna de la Laguna Mar Chiquita es el cangrejo grápsido Cyrtograpsus angulatus (Spivak et al., 1994). Esta especie tiene una amplia distribución desde Río de Janeiro, Brasil, hasta Puerto Deseado, Argentina, en la costa atlántica, y desde la Isla San Lorenzo, Perú, hasta Talcahuano, Chile, en el Pacífico. Habita las zonas inter y submareales en costas rocosas, pero penetra en estuarios (Spivak, 1997). En la Laguna Mar Chiquita, los adultos y juveniles grandes de C. angulatus alcanzan altas densidades en los fondos barrosos, en tanto que las megalopas, reclutas y juveniles pequeños son encontrados casi exclusivamente en los arrecifes de $F$. enigmaticus (Spivak et al., 1994; Luppi et al., 2002b). El reclutamiento de C. angulatus en los arrecifes de F. enigmaticus ha sido intensamente estudiado, y a lo largo del período de reclutamiento se han detectado varios picos de reclutamiento masivo (Luppi, 1999). Por otra parte, se ha demostrado experimentalmente, en el laboratorio y en el campo, la importancia de los arrecifes como refugio contra la depredación y el canibalismo, indicados como los factores más importantes que intervienen en la regulación del reclutamiento. Además, las megalopas de C. angulatus seleccionan como lugar de asentamiento los arrecifes, frente a la opción de hacerlo en el barro circundante (Luppi et al., 2002b).

En este trabajo evaluamos el rol de los arrecifes de F. enigmaticus, una especie invasora, en el reclutamiento de C. angulatus en la Laguna Mar Chiquita. Esta evaluación se llevó a cabo mediante la integración de información preexistente sobre el desarrollo de los arrecifes de $F$. enigmaticus en la Laguna Mar Chiquita, sobre su importancia en la supervivencia de reclutas de $C$. angulatus y sobre la dinámica temporal del reclutamiento de $C$. angulatus, con nuevos datos sobre la densidad y biomasa de reclutas y juveniles de $C$. angulatus. A partir de ello estimamos el volumen total de arrecifes que pueden contener reclutas y el número y biomasa total de reclutas contenidos en los mismos, a lo largo de una estación de reclutamiento. Dado que no existen estudios sobre el reclutamiento de C. angulatus previos a la invasión, se discute acerca del impacto ocasionado por el establecimiento de $F$. enigmaticus sobre el reclutamiento del cangrejo. the tubes are sediment filled (Obenat and Pezzani, 1994). Obenat (unpublished data) estimated the abundance of live worms in reefs, considering three concentric areas of them: outer ring, medium and center. She found that most of the alive worms in reefs (50 to $100 \%$ ) were in the outer ring.

One of the most important components of the macroepifauna of the Mar Chiquita Lagoon is the grapsid crab Cyrtograpsus angulatus (Spivak et al., 1994). This species has a broad distribution extending from Río de Janeiro, Brazil, to Puerto Deseado, Argentina, on the Atlantic Ocean, and from Isla San Lorenzo, Peru, to Talcahuano, Chile, in the Pacific. It inhabits the intertidal and subtidal zones in rocky shores and penetrates into estuaries (Spivak, 1997). In the Mar Chiquita Lagoon, Cyrtograpsus angulatus adults and large juveniles reach high densities in the muddy bottom, while megalopae and small juveniles are found almost exclusively in reefs of F. enigmaticus (Spivak et al., 1994; Luppi et al., 2002b). Cyrtograpsus angulatus recruitment in F. enigmaticus reefs has been extensively studied (Luppi, 1999) and several massive recruitment peaks were found during its long recruitment period. On the other hand, it was experimentally shown, in the field and at the laboratory, the importance of reefs as refuges to prevent predation and cannibalism, described both like the most important factors that regulate its recruitment. In addition, $C$. angulatus megalopae prefer reefs to settle instead of the mud surronding them (Luppi et al., 2002b).

In this work, we evaluated the role played by $F$. enigmaticus, in the recruitment of $C$. angulatus. We integrated preexisting information about reef development in Mar Chiquita, their importance in C. angulatus recruit survival, and recruitment dynamics, with new data on recruit and juvenile density and biomass. From this, we estimated the total volume of reefs able to host recruits and juveniles, and then, total crab number and biomass in the reef per recruitment period. Since there are no data on $C$. angulatus recruitment prior to the F. enigmaticus invasion, we speculate about the impact of the reef development on crab recruitment.

\section{Materials and methods}

\section{Study area}

Mar Chiquita is a coastal lagoon of about $46 \mathrm{~km}^{2}\left(37^{\circ} 32^{\prime}-\right.$ $37^{\circ} 45^{\prime} \mathrm{S} ; 57^{\circ} 19^{\prime}-57^{\circ} 26^{\prime} \mathrm{W}$ ) that runs parallel to the coast from north to south. It is divided into a broad northern part and a narrow southern part, which communicates with the open sea (fig. 1). Small rivers supply it with freshwater, and seawater enters and leaves daily with semidiurnal high tides (Anger et al., 1994). The extent of this water exchange depends on the tidal amplitude and the wind (Reta et al., 2001). Maximal depth is $1.2 \mathrm{~m}$ at the lowest tide level. In spring, physical conditions are highly variable and oligohaline waters are common inside the lagoon for long periods (Anger et al., 1994). In summer, hyperhaline conditions ( $\mathrm{ca} .52 \%$ ) are frequent in shallow waters, caused by high evaporation (Fasano et al., 1982). 


\section{Materiales y métodos}

Área de estudio

Mar Chiquita es una laguna costera de alrededor de $46 \mathrm{~km}^{2}$ $\left(37^{\circ} 32^{\prime}-37^{\circ} 45^{\prime} \mathrm{S} 57^{\circ} 19^{\prime}-57^{\circ} 26^{\prime} \mathrm{W}\right)$ y se ubica paralela a la costa en dirección norte-sur. Se divide en una parte amplia al norte y una parte estrecha al sur, la cual se comunica con el mar abierto (fig. 1). Algunos pequeños arroyos la alimentan con agua dulce, y el agua de mar entra diariamente con las altas mareas semidiurnas (Anger et al., 1994). La intensidad del intercambio de agua de mar depende de la amplitud de la marea y de la dirección e intensidad del viento (Reta et al., 2001). La profundidad máxima durante la marea baja es de 1.2 m. En primavera las condiciones físicas del agua son altamente variables y masas de agua oligohalinas son comunes en el interior de la laguna por extensos periodos (Anger et al., 1994). En el verano, las condiciones hiperhalinas ( $c a$. 52\%o) son frecuentes en las aguas someras, debido a la intensa evaporación (Fasano et al., 1982).

\section{Volumen total de arrecife vivo}

El volumen total de arrecife vivo (VTAV) en la Laguna Mar Chiquita fue estimado con la ecuación

$$
V T A V=(d / 2)^{2} \times \pi \times h \times p v a v \times d p \times a M C
$$

donde $d$ es el diámetro promedio de los arrecifes, $h$ es su altura, pvav es la proporción del volumen de arrecife con gusanos vivos con respecto al volumen total del arrecife (sólo la fracción viva del arrecife es habitada por $C$. angulatus), $d p$ es la densidad promedio de arrecifes por hectárea, y $a M C$ es el área de la Laguna Mar Chiquita donde hay presencia de arrecifes. Las estimaciones de los valores involucrados en los cálculos de $V T A V$ se dan en la tabla 1 . Los valores de $d, d p$ y $a M C$ se tomaron de investigaciones realizadas por Schwindt et al. (1999) y Schwindt (2001). En ellas, los autores estimaron cada una de las variables en base a fotografías aéreas de la Laguna Mar Chiquita provenientes de dos años, 1975 y 1999, para evaluar el crecimiento de los arrecifes en el período transcurrido.

Número y biomasa de reclutas y pequeños juveniles de cangrejo dentro de los arrecifes

El número y biomasa de reclutas y pequeños juveniles de $C$. angulatus que ocupan el interior de los arrecifes fue estimado a partir de datos previos y nuevos. La información necesaria sobre la dinámica del reclutamiento de $C$. angulatus que utilizamos fue extraída de resultados y del reanálisis de datos provenientes de un estudio de 3 años de muestreos periódicos en un sitio de la Laguna Mar Chiquita, realizado por Luppi (1999). En este estudio se mostró que a lo largo de todo un período de reclutamiento, desde principios del verano hasta principios del otoño, se pueden detectar 3 o 4 picos de

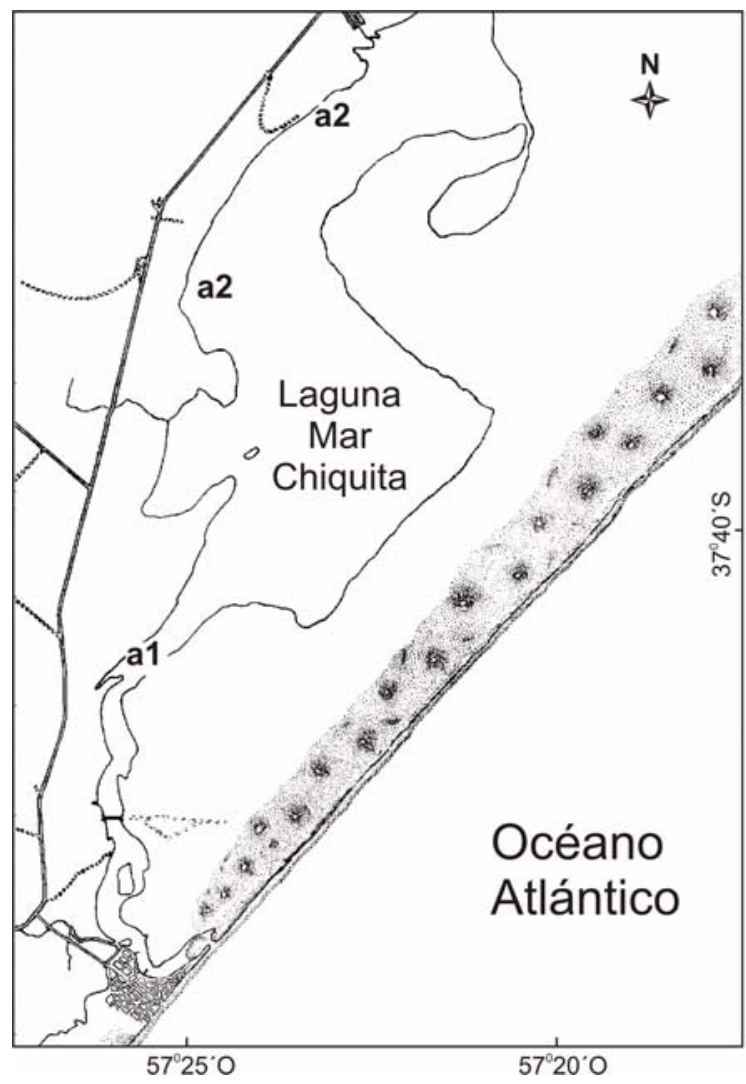

Figura 1. Geografía de la Laguna Mar Chiquita y ubicación de los sitios de muestreo (a1, a2 y a3).

Figure 1. Mar Chiquita Lagoon geography and location of the reef sampling sites (a1, a2 y a3).

Total volume of living reef

The total volume of living reef $(T V L R)$ at Mar Chiquita lagoon was estimated from the equation

$$
T V L R=(d / 2)^{2} \times \pi \times h \times p v l r \times a d \times a M C
$$

where $d$ is the average reef diameter, $h$ is the reef height, $p v l r$ is the ratio between living reef volume and the total reef volume (the only part of the reef inhabited by Cyrtograpsus angulatus), ad is the average density of reefs per ha, and $a M C$ is the area of the Mar Chiquita Lagoon where reefs are present. Estimates of the values involved in the calculation of TVLR are given in table 1 . Values of $d, a d$ and $a M C$ were taken from research by Schwindt et al. (1998) and Schwindt (2001). There, these authors estimated variables from 1975 and 1999 aerial photographs of the Mar Chiquita Lagoon to asses the reefs' growth during that period.

Number and biomass of recruits and small juveniles of Cyrtograpsus angulatus inside reefs

The number and biomass of small juveniles of $C$. angulatus inside living reefs was estimated from existing and new data. 
Luppi y Bas: Rol de arrecifes invasores en el reclutamiento de un cangrejo nativo

Tabla 1. Datos y resultados sobre arrecifes de Ficopomatus enigmaticus para 1975 y 1999. $d=$ diámetro promedio de los arrecifes; $h=$ alto de los arrecifes; $p v a v=$ proporción de volumen de arrecife vivo; $d p=$ densidad promedio de arrecifes; $a M C=$ área de la Laguna Mar Chiquita donde los arrecifes están presentes; VTAV = volumen total de arrecife vivo.

Table 1. Data and results about Ficopomatus enigmaticus reefs for 1975 and 1999. $d=$ mean reef diameter; $h=$ height of the reef; $\operatorname{pvav}(p v / r)=$ living reef to total reef volume ratio; $d p(a d)=$ mean reef density; $a M C=$ Mar Chiquita Lagoon area where reefs are present; VTAV (TVLR): total volume of living reef.

\begin{tabular}{lllcccc}
\hline Año & $\begin{array}{l}d^{*} \\
(\mathrm{~m})\end{array}$ & $\begin{array}{c}h^{* *} \\
(\mathrm{~m})\end{array}$ & $p v a v^{*}$ & $\begin{array}{c}d p^{*} \\
\left.(\operatorname{arrecifes~ha})^{-1}\right)\end{array}$ & $\begin{array}{c}a M C^{*} \\
(\mathrm{ha})\end{array}$ & $\begin{array}{c}V^{*} \\
\left(\mathrm{~m}^{3}\right)\end{array}$ \\
\hline 1975 & 1.67 & 0.5 & 0.55 & 71.4 & 3,968 & 171,405 \\
1999 & 2.17 & 0.5 & 0.55 & 87.6 & 3,968 & 353,849 \\
\hline
\end{tabular}

* Schwindt et al. (1999); ** Obenat y Pezzani (1994); * este trabajo / this work

reclutamiento masivo (PRM) de C. angulatus en los arrecifes de F. enigmaticus, evidenciados por la picos de alta densidad de megalopas y cangrejos en el primer estadio. Por otra parte, también se obtuvieron las distribuciones de frecuencias de tallas (DFT) de reclutas y juveniles a lo largo de los 3 periodos de reclutamiento sucesivos. Nosotros comparamos las DFTs (tomadas de Luppi et al., 2002a) del período de reclutamiento de 1995 (enero-abril) mediante el test de $\chi^{2}$. Para estimar la densidad de reclutas y pequeños juveniles en distintos momentos del período de reclutamiento, se obtuvieron muestras de arrecifes en enero y marzo de 1995 en tres sitios de la laguna (a1, a2 y a3, fig. 1). Diez muestras de $300 \mathrm{~cm}^{3}$ de arrecife tomadas con un sacabocado fueron extraídas en cada sitio y fecha de muestreo. Las muestras fueron transportadas inmediatamente al laboratorio, se extrajeron todos los cangrejos de los trozos de arrecife y se midieron mediante un estereomicroscopio o calibre, dependiendo del tamaño del individuo, con una precisión de $0.1 \mathrm{~mm}$. Para cada fecha de muestreo, fue construída una DFT con un tamaño de clase de $1 \mathrm{~mm}$. Se calculó la densidad de cada clase de talla y la densidad total $(D T)$ por 300 $\mathrm{cm}^{3}$ de muestra y se expresó en los cálculos como individuos $\mathrm{m}^{-3}$. Las diferencias de las densidades entre sitios fueron analizadas mediante un ANOVA no paramétrico, Kruskal-Wallis (Zar, 1996).

La biomasa (como peso húmedo) de reclutas y pequeños juveniles fue estimada de una muestra de arrecife de $8,000 \mathrm{~cm}^{3}$ tomada en abril de 1999. Todos los cangrejos fueron medidos (AC) y pesados (precisión $0.01 \mathrm{mg}$ ), y asignados a clases de talla de $1 \mathrm{~mm}$ para estimar el peso promedio de cada clase de talla. La biomasa de reclutas y pequeños juveniles por unidad de volumen de arrecife vivo $(B)$ fue expresado como $\mathrm{g} \mathrm{m}^{-3} \mathrm{y}$ calculado como la suma de los productos de las densidades por los pesos promedio de cada clase de talla, para cada PRM, tal como se expresa en

$$
B=\sum_{i}^{n} d_{i} \times p_{i}
$$

donde $d_{i}$ y $p_{i}$ son la densidad y el peso promedio para una clase de talla dada.
Information about $C$. angulatus recruitment dynamics was taken from results of a three-year study with periodical sampling at one site of the Mar Chiquita Lagoon and reanalysed (Luppi, 1999). In this study it was shown that three or four massive recruitment peaks (MRP) appeared throughout each recruitment period, between early summer and early fall, when high density peaks of megalopae and crabs occurred in F. enigmaticus reefs. In the same study, size frequency distributions (SFD) were made for recruits and juveniles along the three succesive sampling years.

We compared the distributions (from Luppi et al., 2002a) of the 1995 recruitment period (January to April) with a $\chi^{2}$ test. To estimate recruits and small juveniles densities in the rest of the lagoon at different times along the recruitment period, we took reef samples in January and March 1995, in three sites of the lagoon (a1, a2 and a3, fig.1). Ten samples of reef, $300 \mathrm{~cm}^{3}$ each, were obtained with a corer in every site and time. They were carried to the laboratory and all the crabs extracted from them were sized $(\mathrm{CW})$ to made size frequency distributions with 1-mm size classes. Density of each class was calculated, and total densty $(T D)$ in $300 \mathrm{cc}$ of reef. Finally it was expressed as individuals $\mathrm{m}^{-3}$. Differences of densities between sites were analysed with non parametrical ANOVA, Kruskal-Wallis (Zar, 1996).

Biomass of recruits and small juveniles (wet weight) was estimated from crabs in a reef sample of $8,000 \mathrm{~cm}^{3}$ taken in April 1999. All crabs were sized (CW) and weighed $(0.01 \mathrm{mg}$ precision) and assigned to a size class (1-mm intervals) to estimate the mean weight of each class. Biomass of recruits and small juveniles per unit of living reef $(B)$ as $\mathrm{g} \mathrm{m}^{-3}$, was estimated as the sum of the products of densities by the mean weights for all the size classes (equation 2), and this was made for each MRP,

$$
B=\sum_{i}^{n} d_{i} \times w_{i}
$$

where $d_{i}$ and $w_{i}$ are density and mean weight for each size class. 
El número total $(N T)$ y la biomasa total $(B T)$ de reclutas y pequeños juveniles en los arrecifes fueron estimados utilizando las ecuaciones

$$
\begin{aligned}
& N T=V T A V \times D T \times N^{\mathrm{o}} \mathrm{PRM} \quad \mathrm{y} \\
& B T=V T A V \times B \times N^{\mathrm{o} P R M,}
\end{aligned}
$$

respectivamente, donde $V T A V$ es el volumen total de arrecife vivo, $D T$ es la densidad total de reclutas y pequeños juveniles por unidad de volumen de arrecife vivo, $N^{\circ} \mathrm{PRM}$ es el número de picos de reclutamiento masivo y $B$ es la biomasa de cangrejos por unidad de volumen de arrecife vivo.

\section{Resultados}

\section{Volumen total de arrecife vivo}

Se estimó un volumen total de arrecife vivo de $171,405 \mathrm{~m}^{3}$ y $353,849 \mathrm{~m}^{3}$, para 1975 y 1999 , respectivamente (tabla 1 ). Consecuentemente, el incremento de volumen fue de $106 \%$ en el lapso de 24 años transcurridos. No existe información sobre la abundancia de arrecifes antes de 1975.

Número y biomasa de reclutas y juveniles pequeños de Cyrtograpsus angulatus

No hubo diferencias significativas en las densidades de reclutas y pequeños juveniles entre los sitios de muestreo $(H=5.8, P>0.05)$, por lo que se utilizó un valor promedio de densidad en todos los cálculos.

Las DFTs cambiaron a lo largo del período de reclutamiento. Al comienzo del verano (muestreos correspondientes al 4-01-1995 y 14-01-1995), cuando el periodo de asentamiento comienza, las distribuciones aparecen desplazadas hacia la izquierda, debido a la gran abundancia de reclutas (fig. 2). Posteriormente (en los muestreos correspondientes al 28-01-1995, febrero, marzo y abril) las distribuciones se muestran más simétricas con un claro predominio de juveniles de tallas intermedias, desde 4 a $6 \mathrm{~mm}$; y este tipo de distribuciones se mantienen sin mayores cambios hasta el fin del periodo de reclutamiento (fig. 2). Las dos primeras DFTs no difieren estadísticamente entre sí, pero sí de las restantes, que a su vez no muestran diferencias significativas entre ellas (fig. 2). Las diferencias entre las DFTs al inicio del periodo de reclutamiento con las restantes se han atribuido, principalmente, al canibalismo (Luppi et al., 2002a). Los autores mostraron que a la llegada de las primeras cohortes de reclutas, la densidad de juveniles predadores dentro de los arrecifes es mínima, pero ésta comienza a aumentar a medida que los reclutas crecen y se convierten en predadores de las cohortes subsiguientes, con lo que la presión de canibalismo sobre los reclutas aumenta y produce su rápida disminución. El mismo patrón de cambio temporal en las DFTs se observó en los años 1993 y 1994, estudiados por Luppi et al., (2002a). De esta forma, el primer
The total number $(T N)$ and total biomass $(T B)$ of recruits and small juveniles inside the reefs were estimated from equations

$$
\begin{aligned}
& T N=T V L R \times T D \times N^{\circ} \mathrm{MRP} \quad \text { and } \\
& T B=T V L R \times B \times N^{\circ} \mathrm{MRP}
\end{aligned}
$$

where TVLR is the total volume of living reef, TD is the total density of recruits and small juveniles per unit of living reef, $N^{\circ}$ MRP is the number of massive recruitment peaks during one recruitment period and $B$ is recruits and small juveniles biomass per living reef volume unit.

\section{Results}

Total volume of living reef

The total volume of living reef was estimated in 171,405 $\mathrm{m}^{3}$ and $353,849 \mathrm{~m}^{3}$ for 1975 and 1999 , respectively (table 1). Consequently, the increase in volume was $106 \%$ over 24 years. There is no information about the abundance of this species before 1975.

Number and biomass of $C$. angulatus small juveniles

There were no significant differences in the recruits and small juveniles densities between sites $(H=5.8, P>0.05)$, therefore, a common mean density value was used in the calculations.

The SFDs changed along the recruitment period. In the early summer, when settlement begins, SFDs appeared skewed to the left, because of the high density of recruits (01-04-1995 and 01-14-1995, fig. 2). After that, SFDs were more symmetric, and juveniles of middle sizes (4-6 mm) clearly predominated. So it was until the end of the recruitment period (01-28-1995 and all samples collected on February, March and April 1995, fig. 2). When statistically tested, the two first January samples are not different, but they differ from the other SFDs, which, on their turn, are not statistically different among them (fig. 2). The differences between the SFDs at the beginning and those during the remaining recruitment period were attributed to cannibalism. Luppi et al. (2002a) showed that when the first recruit cohorts arrive, the density of predator juveniles inside the reefs is minimal, and it begins to grow up while recruits grow in size and become predators of the next cohort. In this way, cannibalism over recruits increases, reducing its density and making small sizes disappear from the SFD. The same SFD pattern change was observed during the 1993 and 1994 recruitment periods (Luppi et al., 2002a). Consequently, the first MRP produces a recruit and small juvenile size distribution similar to that observed in the first 


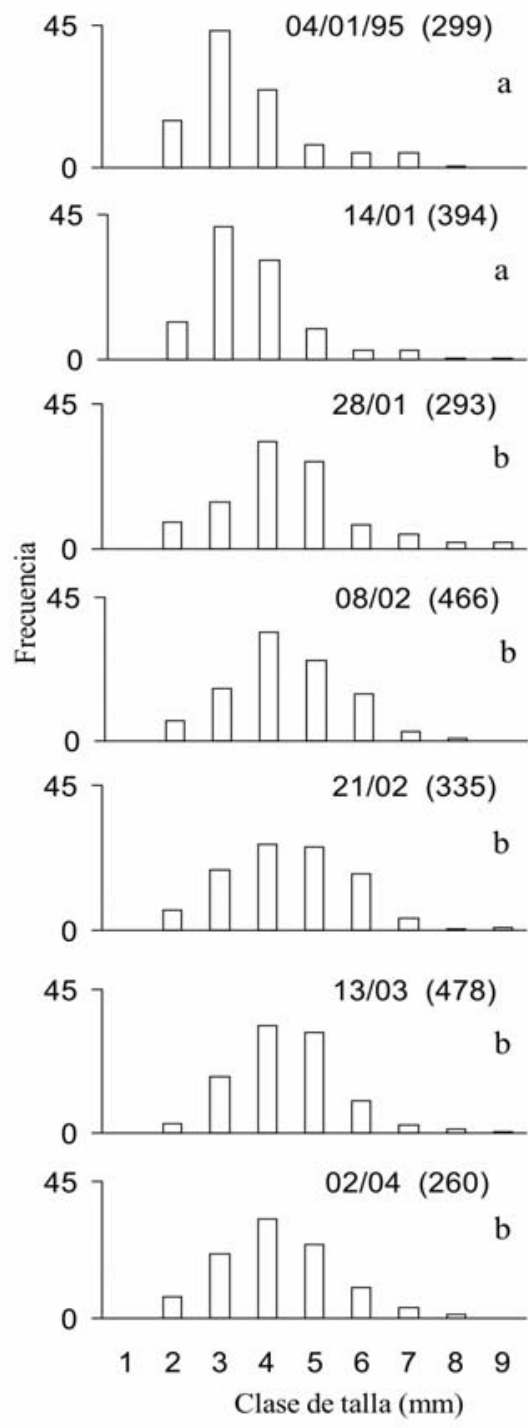

Figura 2. Distribución de frecuencia de tallas de reclutas y pequeños juveniles de Cyrtograpsus angulatus a lo largo del periodo de reclutamiento correspondiente a 1995. Letras minúsculas iguales determinan distribuciones de frecuencias de tallas estadísticamente similares. Los números entre paréntesis indican el tamaño de muestra.

Figure 2. Size frequency distribution of recruits and small juveniles of Cyrtograpsus angulatus throughout the 1995 recruitment period. Size frequency distributions with the same lowercase letters are not statistically different. Numbers in braquets indicate the sample size.

PRM produce una distribución de tallas de reclutas y juveniles similar a las dos primeras distribuciones de enero de 1995, y los posteriores $2^{\circ}, 3^{\circ}$ y $4^{\circ}$ PRMs producen distribuciones de tallas similares a las del resto del verano. De esta manera, la muestra tomada en enero de 1995, destinada a estimar la variación de la densidad de reclutas y juveniles en la laguna, es tomada como representativa del primer PRM, y la muestra de marzo de 1995 como representativa de $\operatorname{los} 2^{\circ}, 3^{\circ}$ y $4^{\circ}$ PRMs.

La figura 3 muestra la densidad de reclutas y pequeños juveniles para cada clase de talla, para el $1^{\mathrm{er}}$ y el $2^{\circ}$ PRMs. La mayor densidad se registró en la clase de talla de $3 \mathrm{~mm}$ (2,167 individuos $\mathrm{m}^{-3}$, fig. 3a) para el $1^{\text {er }} \mathrm{PRM}$, y de $6 \mathrm{~mm}$
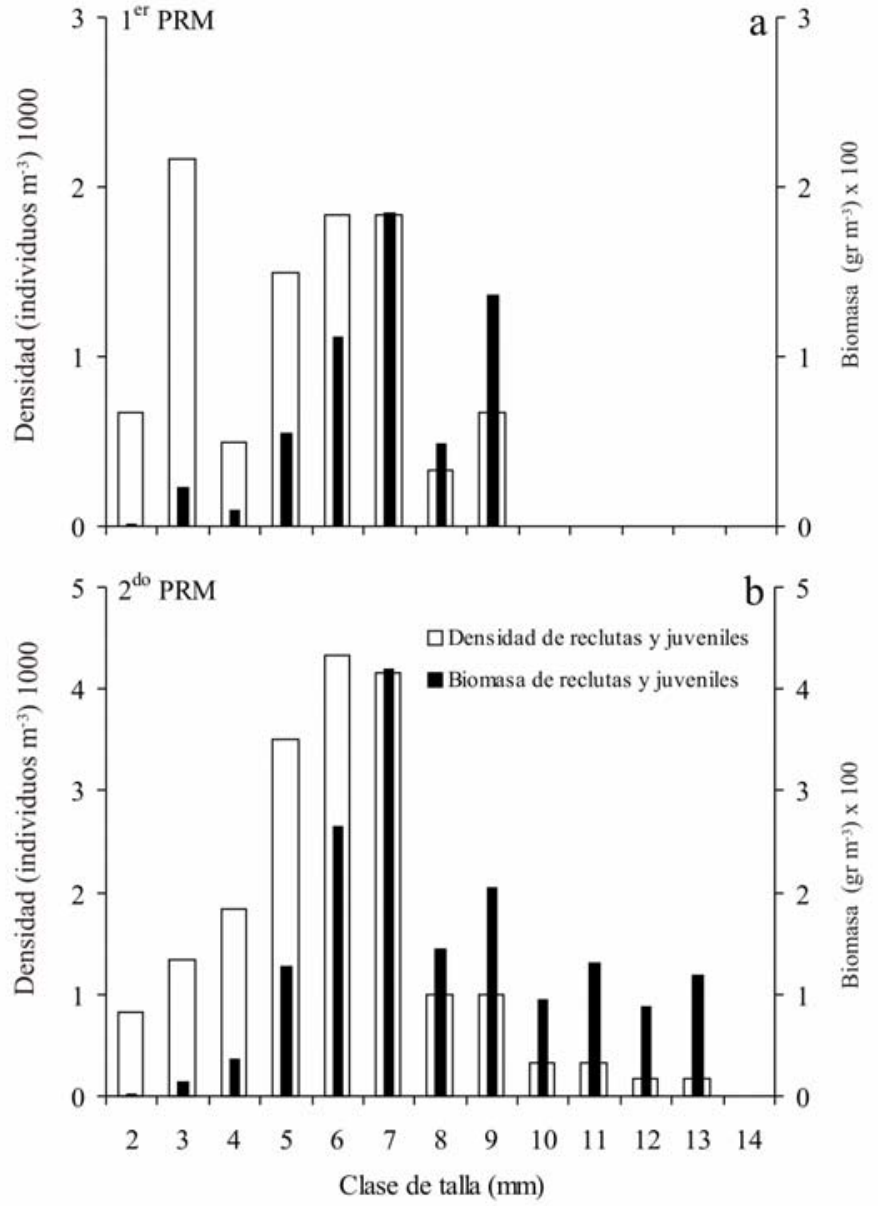

Figura 3. Densidad (individuos $\left.\mathrm{m}^{-3}\right)$ y biomasa $\left(\mathrm{gr} \mathrm{m}^{-3}\right)$ de reclutas y pequeños juveniles de Cyrtograpsus angulatus para cada clase de talla (1 $\mathrm{mm}$ ) para el primero (a) y segundo (b) picos de reclutamiento masivo (PRM).

Figure 3. Density (individuals $\left.\mathrm{m}^{-3}\right)$ and biomass $\left(\mathrm{gr} \mathrm{m}^{-3}\right)$ of recruits and small juveniles of Cyrtograpsus angulatus at each size class $(1 \mathrm{~mm})$ for the first (a) and the second (b) mass recruitment peaks (PRM).

two January 1995 SFDs, and the following $2^{\text {nd }}, 3^{\text {rd }}$ and $4^{\text {th }}$ MRPs produce SFDs similar to those seen in the rest of the summer. For this reason, the sample taken on January 1995 and used to estimate recruit and small juvenile density in the lagoon is considered representative of the first MRP and the sample taken in March of the same year is representative of the $2^{\text {nd }}, 3^{\text {rd }}$ and $4^{\text {th }}$ MRPs.

The recruit and small juvenile densities for each size class, in the first and second MRPs, are shown in figure 3. The highest densities are found in the $3-\mathrm{mm}\left(2,167\right.$ individuals $\mathrm{m}^{-3}$, fig. 3a) and the $6-\mathrm{mm}$ size classes (4,333 individuals $\mathrm{m}^{-3}$, fig. 3b), for the $1^{\text {st }}$ and $2^{\text {nd }}$ MRPs respectively. Total densities were 9,667 individuals $\mathrm{m}^{-3}$ and 12,667 individuals $\mathrm{m}^{-3}$ respectively. Densities during the $3^{\text {rd }}$ and $4^{\text {th }}$ MRPs were considered equal to that during the second because of the similar SFD described previously. The total number of recruits and small juveniles inside the reefs at the Mar 
(4,333 individuos $\mathrm{m}^{-3}$, fig. $3 \mathrm{~b}$ ) para el $2^{\circ}$ PRM. Las densidades totales fueron de 9,667 individuos $\mathrm{m}^{-3}$ y 12,667 individuos $\mathrm{m}^{-3}$, respectivamente. Las densidades correspondientes al $3^{\circ}$ y $4^{\circ}$ PRMs fueron consideradas equivalentes al $2^{\circ} \mathrm{PRM}$, debido a la similitud en las distribuciones de frecuencia de tallas descritas anteriormente. El número total de reclutas y pequeños juveniles dentro de los arrecifes en la Laguna Mar Chiquita, calculado mediante la ecuación 3 fue, con 3 PRMs,

$$
\begin{aligned}
N T & =353,849 \mathrm{~m}^{3} \times\left(9,667 \text { ind. } \mathrm{m}^{-3}+\left(12,667 \text { ind. } \mathrm{m}^{-3} \times 2\right)\right) \\
& =1.24 \times 10^{10} \text { individuos; }
\end{aligned}
$$

y con 4 PRMs,

$$
\begin{aligned}
N T & =353,849 \mathrm{~m}^{3} \times\left(9,667 \text { ind. } \mathrm{m}^{-3}+\left(12,667 \text { ind. } \mathrm{m}^{-3} \times 3\right)\right) \\
& =1.69 \times 10^{10} \text { individuos. }
\end{aligned}
$$

El peso húmedo promedio de cada clase de talla de reclutas y pequeños juveniles varió desde $0.002 \mathrm{~g}$ (clase de 1-2 mm), hasta $0.892 \mathrm{~g}$ (clase de 13-14 mm) (fig. 4). La biomasa de cangrejos por unidad de volumen de arrecife vivo fue de 0.569 $\mathrm{kg} \mathrm{m}^{-3}$ para el $1^{\mathrm{er}} \mathrm{PRM}$, y de $1.644 \mathrm{~kg} \mathrm{~m}^{-3}$ para los PRMs subsecuentes. La biomasa total de reclutas y pequeños juveniles que se encuentran dentro de los arrecifes en la Laguna Mar Chiquita, calculada mediante la ecuación 4 fue, con 3 PRMs,:

$$
\begin{aligned}
B T & =353,849 \mathrm{~m}^{3} \times\left(0.569 \mathrm{~kg} \mathrm{~m}^{-3}+\left(1.644 \mathrm{~kg} \mathrm{~m}^{-3} \times 2\right)\right) \\
& =1,364,795 \mathrm{~kg} ;
\end{aligned}
$$

y con 4 PRMs,

$$
\begin{aligned}
B T & =353,849 \mathrm{~m}^{3} \times\left(0.569 \mathrm{~kg} \mathrm{~m}^{-3}+\left(1.644 \mathrm{~kg} \mathrm{~m}^{-3} \times 3\right)\right) \\
& =1,946,523 \mathrm{~kg} .
\end{aligned}
$$

\section{Discusión}

A pesar del impacto que se les atribuye a las especies invasoras, el efecto real de la mayoría de las invasiones permanece desconocido. Los estudios que analizan los cambios temporales y/o espaciales de las poblaciones o comunidades asociadas a una invasión, y la prueba de hipótesis sobre las relaciones causa efecto involucradas son muy escasos (Ruíz et al., 1997). En este trabajo, se evaluó el impacto de un poliqueto invasor sobre un cangrejo nativo, considerado una especie clave de la comunidad, y se propone cuales serían los cambios introducidos en el ecosistema que modificaron directamente la población nativa y, en consecuencia, toda la comunidad.

El desarrollo de arrecifes de Ficopomatus enigmaticus y su rol ecológico esta bien documentado en otros ambientes (ten Hove y van den Hurk, 1993; Bianchi y Morri, 1994; Fornos et al., 1997). Estos arrecifes proveen refugio a muchos invertebrados y forman "islas" de alta diversidad en comunidades bentónicas poco diversas. Sin embargo, los arrecifes no han sido relacionados con el asentamiento y reclutamiento de decápodos y sólo recientemente se ha mencionado su función

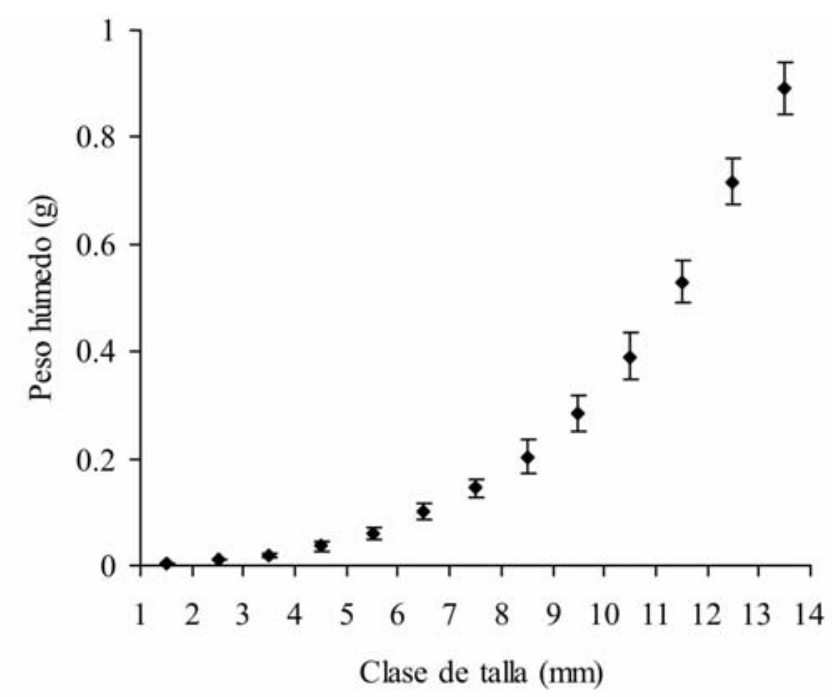

Figura 4. Peso húmedo (promedio \pm d.e.) de reclutas y pequeños juveniles de Cyrtograpsus angulatus ordenados por clases de talla de $1 \mathrm{~mm}$.

Figure 4. Wet weight (means \pm s.d.) of recruits and small juveniles of Cyrtograpsus angulatus at each size class of $1 \mathrm{~mm}$.

Chiquita Lagoon, calculated from equation 3 was, considering 3 MRPs,

$$
\begin{aligned}
T N & =353,849 \mathrm{~m}^{3} \times\left(9,667 \text { ind. } \mathrm{m}^{-3}+\left(12,667 \text { ind. } \mathrm{m}^{-3} \times 2\right)\right) \\
& =1.24 \times 10^{10} \text { individuals; }
\end{aligned}
$$

and with 4 MRPs,

$$
\begin{aligned}
T N & =353,849 \mathrm{~m}^{3} \times\left(9,667 \text { ind. } \mathrm{m}^{-3}+\left(12,667 \text { ind. } \mathrm{m}^{-3} \times 3\right)\right) \\
& =1.69 \times 10^{10} \text { individuals. }
\end{aligned}
$$

The mean wet weight of each size class ranged from $0.002 \mathrm{~g}$ (1-2 mm class), to $0.892 \mathrm{~g} \mathrm{(13-14} \mathrm{mm} \mathrm{class)} \mathrm{(fig.} \mathrm{4).}$ The crab biomass per living reef volume unit was $0.569 \mathrm{~kg} \mathrm{~m}^{-3}$ of living reef for the first MRP, and $1.644 \mathrm{~kg} \mathrm{~m}^{-3}$ for the subsequent ones. The total biomass of recruits and small juveniles in the reefs at the Mar Chiquita Lagoon, calculated from equation 4 was, with 3 MRPs,

$$
\begin{aligned}
T B & =353,849 \mathrm{~m}^{3} \times\left(0.569 \mathrm{~kg} \mathrm{~m}^{-3}+\left(1.644 \mathrm{~kg} \mathrm{~m}^{-3} \times 2\right)\right) \\
& =1,364,795 \mathrm{~kg}
\end{aligned}
$$

and with 4 MRP,

$$
\begin{aligned}
T B & =353,849 \mathrm{~m}^{3} \times\left(0.569 \mathrm{~kg} \mathrm{~m}^{-3}+\left(1.644 \mathrm{~kg} \mathrm{~m}^{-3} \times 3\right)\right) \\
& =1,946,523 \mathrm{~kg} .
\end{aligned}
$$

\section{Discussion}

Despite the significant impact ascribed to some invasive species, the effects of most of the invasions remain unknown. Studies analyzing spatial or temporal changes in a population or community associated with an invasion are very scarce, as 
Luppi y Bas: Rol de arrecifes invasores en el reclutamiento de un cangrejo nativo

como hábitat de decápodos adultos (Schwindt, 2001). En cambio, otros arrecifes de gusanos sabeláridos en ambientes mixo-eurihalinos o polihalinos son habitados frecuentemente por cangrejos (Gore et al., 1978; Haines y Maurer, 1980; Heck y Hambrook, 1991; Gherardi y Cassidy, 1993; Pinheiro et al., 1997; Flores y Negreiros-Fransozo, 1999).

Los reclutas y pequeños juveniles de $C$. angulatus también se encuentran en estructuras biogénicas nativas como lechos de valvas del bivalvo Tagelus plebeius (Gutierrez e Iribarne, 1999), entre guijarros (Spivak et al., 1994) y en sedimentos de tosca (Bas, observación personal), pero, estos refugios "nativos" son comparativamente escasos en relación con los arrecifes de los poliquetos. La densidad de cangrejos en los lechos de valvas, el más importante y complejo de los refugios nativos, es de 21.75 individuos $\mathrm{m}^{-2}$ (Gutierrez e Iribarne, 1999). Cerca de la boca de la laguna, éstos refugios ocupan una angosta zona intermareal (Gutierrez e Iribarne, 1999), que representa un $11.5 \%$ del bentos. Según nuestras observaciones, es razonable proyectar la misma proporción de cobertura para el resto de la laguna, lo que resulta en un área de 529 ha cubiertas por lechos de valvas. El número total de reclutas y pequeños juveniles en los lechos de valvas, considerando 4 PRMs, podría llegar así a $4.60 \times 10^{6}$ individuos, un $2.72 \%$ del total de cangrejos estimados en los arrecifes para el mismo período.

Desafortunadamente, no existen datos sobre la intensidad del reclutamiento previo a la invasion de F. enigmaticus en la Laguna Mar Chiquita. Tampoco disponemos de un ambiente de características similares a esta laguna, con una comunidad comparable pero sin la presencia de bochones, que nos pudiera servir de ambiente control para este estudio. De esta forma, es muy dificil establecer el impacto real de los arrecifes en el reclutamiento de $C$. angulatus, dado que la densidad de reclutas en los refugios "nativos" puede estar muy alterada, tanto en más como en menos, por la misma presencia de los arrecifes en la laguna.

Aún así, existen dos hechos que nos permiten especular con bastante sustento acerca de la importancia de la presencia de F. enigmaticus. En primer lugar, las estimaciones de la densidad de reclutas hechas por Gutierrez e Iribarne (1999) en los lechos de valvas están realizadas en una zona de la laguna (sino la única) donde prácticamente no se encuentran arrecifes y las primeras concentraciones importantes aparecen a más de 1,000 m. Esta distancia puede resultar lo suficientemente extensa como para mitigar posibles migraciones de reclutas desde o hacia los arrecifes, creando así un ambiente "libre de arrecifes". Por otra parte, aún considerando que la densidad de reclutas fuera mayor en el pasado, el área de refugio provista por los lechos de valvas, es siempre comparativamente mucho menor a la de F. enigmaticus, dado el crecimiento tridimensional de los arrecifes y su extensión areal. De este modo es posible suponer que el reclutamiento de $C$. angulatus se ha incrementado varios órdenes de magnitud a partir de la presencia y desarrollo de F. enigmaticus en la laguna.

A partir de estudios previos se conoce que la disponibilidad de refugios es fundamental para que la supervivencia y el well as testing hypothesis about the cause-effect relationships involved (Ruíz et al., 1997). Here, the impact of an invasive polychaete on a native crab was evaluated, and the changes introduced in the ecosystem that most directly modify native populations, and perhaps the whole community, were determined.

The development of Ficopomatus enigmaticus reefs and their ecological role have been well documented in other estuarine environments (ten Hove and van den Hurk, 1993; Bianchi and Morri, 1994; Fornos et al., 1997). These reefs provide refuge to many invertebrates and form "islands" of high diversity in scarcely diverse benthic communities. Nevertheless, this reefs have not been related to the juvenile decapods settlement and recruitment, and their role as adult habitat was just recently mentioned (Schwindt, 2001). Instead, sabellariid reefs, commonly found in mixo-eurihaline or polyhaline environments are frequently inhabited by crabs (Gore et al., 1978; Haines and Maurer, 1980; Heck and Hambrook, 1991; Gherardi and Cassidy, 1993; Pinheiro et al., 1997; Flores and NegreirosFransozo, 1999).

Recruits and small juveniles of $C$. angulatus use also biogenic structures as refuge like valve beds of the bivalve Tagelus plebeius (Gutierrez and Iribarne, 1999), cobbles (Spivak et al., 1994) and emergent consolidated sediments (Bas, personal observation), these "native" refuges are comparatively scarce when compared to polychaete reefs. Small crab density in valve beds, the most important and complex of native refuges, is 21.75 juveniles $\mathrm{m}^{-2}$ (Gutierrez and Iribarne, 1999). Near the mouth of the lagoon, valve beds occupy a narrow intertidal zone (Gutierrez and Iribarne, 1999) that represents $11.5 \%$ of the benthos. As we observed, it is reasonable to project the same cover proportion to the rest of the lagoon, which results in a 529-ha area covered by valve beds. The total number of juveniles in the valve beds, considering 4 annual MRPs, would account for $4.60 \times 10^{6}$ individuals, $2.72 \%$ of the total number estimated in reefs for the same period.

Unfortunately, there are no data about $C$. angulatus recruitment in the Mar Chiquita Lagoon prior to the $F$. enigmaticus invasion. Neither we have an environment similar to Mar Chiquita but without reefs, to use it as a control in our study, and so, it is difficult to establish the actual impact of the reefs on the $C$. angulatus recruitment given that recruit density in "native" refuges may be now more or less altered by the presence of reefs. Even so, there are two facts that allow us to speculate about the importance of the $F$. enigmaticus presence. First, the estimation of recruit density in valve beds was made by Gutiérrez and Iribarne (1999) in a zone of the lagoon (perhaps the only one) where reefs are practically absent, and the first important reefs appear about 1,000 $\mathrm{m}$ away. That distance can be enough to preclude possible recruit migration from or to reefs and, therefore it may be considered a "reef-free zone". Secondly, even considering that recruit density in the valve beds were higher in the past, the refuge area they provide is too small compared with the area covered by $F$. enigmaticus, and its three-dimensional reef growth. So, it is possible that 
reclutamiento de C. angulatus sea exitoso (Luppi et al., 2001; Luppi et al., 2000b). Una de las mayores causas de mortalidad de reclutas es el canibalismo por juveniles, y experimentos de laboratorio y de campo mostraron que la disponibilidad de un refugio reduce significativamente este canibalismo. Además, las megalopas eligen activamente los arrecifes como hábitat de asentamiento. La disponibilidad de refugios adecuados en el ambiente puede crear un cuello de botella en la historia de vida de $C$. angulatus, hecho observado en otras especies de cangrejo (e.g. Beck, 1997; Kneib et al., 1999). Entonces, el impacto de la invasión de $F$. enigmaticus sobre el reclutamiento de $C$. angulatus consiste en un incremento en la disponibilidad de refugios (via un incremento de la diversidad física y la tridimensionalidad del bentos, sensu Ruíz et al., 1997; Olenin y Leppäkoski, 1999) para reclutas y pequeños juveniles y, consecuentemente, en la expansión del cuello de botella poblacional.

La densidad de adultos de $C$. angulatus en la Laguna Mar Chiquita es alta, pero variable en tiempo y espacio. Tiene un rango desde 3,000 hasta 34,000 individuos $\mathrm{ha}^{-1}$ en un mismo sitio, y alcanza 400,000 individuos ha ${ }^{-1}$ en algunos lugares, cuando los individuos se agregan, presumiblemente con fines reproductivos (Bas, datos no publicados). Los arrecifes pueden actuar como fuente de juveniles para mantener este elevado stock de adultos. Por otra parte, los juveniles que abandonan los arrecifes son altamente canibalizados por los adultos, vehiculizándose de esta manera recursos desde el interior de los arrecifes hacia el exterior de los mismos (Gavio e Iribarne, 1994; Luppi et al., 2001).

El gran número y biomasa de reclutas y pequeños juveniles de $C$. angulatus que viven en los arrecifes no sólo juegan un rol importante en la dinámica poblacional de la misma especie, sino que también pueden afectar a otros miembros de la comunidad. Peces juveniles que utilizan la Laguna Mar Chiquita como área de cría incluyen en sus dietas a reclutas y juveniles de C. angulatus (Hozborn y García de la Rosa, 2000; Escalante, 2001; Rivera-Prisco et al., 2002). De la misma manera, varias especies de peces y aves se alimentan de adultos de $C$. angulatus (Olivier et al., 1972; Spivak y Sánchez, 1992; Bachmann, 1999).

Ficopomatus enigmaticus se ha transformado en un elemento estructural clave en la comunidad bentónica de Mar Chiquita, modificando la homogeneidad del sustrato original, y actuando como trampa de sedimento, reteniendo partículas que de otro modo serían transportadas al exterior de la laguna (Schwindt e Iribarne, 1998), disminuyendo gradualmente, de esta manera, la profundidad media (Fasano et al., 1982) y afectando la abundancia y el transporte de la macro y meiofauna (Schwindt, 2001). Además, los arrecifes también son utilizados por cangrejos adultos de C. angulatus y Chasmagnathus granulatus, y se ha estimado que $11 \times 10^{6}$ adultos de C. angulatus viven debajo de los arrecifes (Schwindt, 2001). Por otra parte, los arrecifes podrían haber incrementado la intensidad del parasitismo, especialmente de trematodos digéneos, sobre los adultos de C. angulatus, actualmente muy alta, dado que son el hábitat de los hospedadores
C. anulatus recruitment has grown exponentialy since F. enigmaticus became established and its reefs have grown up in the lagoon.

From previous works refuge availability is known to be fundamental for the successful C. angulatus recruitment and survivorship (Luppi et al., 2001; Luppi et al., 2002b). One of the most important causes of recruits' mortality is cannibalism by large juveniles, and laboratory and field experiments showed that refuge availability significantly reduced intraspecific predation and that the reef is actively chosen as a settlement habitat by megalopae. The availability of suitable refuge may create a "bottleneck" in the C. angulatus life history, similar to that observed for other crab species (e.g. Beck, 1997; Kneib et al., 1999). The impact of $F$. enigmaticus on C. angulatus recruitment consists, then, in an increased availability of refuge sites (by increasing physical diversity and benthos three-dimensionality, sensu Ruíz et al., 1997; Olenin and Leppäkoski, 1999) for recruits and small juveniles and consequently an expansion of the population "bottleneck".

The density of C. angulatus adults in Mar Chiquita Lagoon is high but variable in time and space. It ranged from 3,000 to 34,000 individuals ha ${ }^{-1}$ at one site, and reached 400,000 individuals $\mathrm{ha}^{-1}$ in some places, when crabs aggregate during their reproductive period (Bas, unpublished data). The reefs may be acting as a source of juveniles that maintains the adult stock. Furthermore, large juveniles are highly cannibalized by adult crabs when they leave the reefs and, in this way, resources move from reefs to other habitats in the lagoon (Gavio and Iribarne, 1994; Luppi et al., 2001).

The high number and biomass of recruits and juveniles of C. angulatus living in the reefs should play an important role not only in the population dynamics of this crab, but also affect other members of the community. Juvenile fishes that use Mar Chiquita as a nursery area include recruits and juveniles of $C$. angulatus in their diets (Hozborn and García-de-la-Rosa, 2000; Escalante, 2001; Rivera-Prisco et al., 2002). Likewise, many species of fish and birds feed on C. angulatus adults (Olivier $e t$ al., 1972; Spivak and Sánchez, 1992; Bachmann, 1999).

Ficopomatus enigmaticus has become a key structural element in the benthic community of Mar Chiquita, modifying the homogeneity of the original substrate, retaining sediments that would otherwise be transported out of the lagoon (Schwindt and Iribarne, 1998), decreasing gradually its mean depth (Fasano et al., 1982) and affecting the macroinfaunal and meiofaunal abundance and transport (Schwindt, 2001). In addition, reefs are also used by adult crabs of $C$. angulatus and Chasmagnathus granulata: it was estimated that $11 \times 10^{6}$ adults of C. angulatus live under the reefs (Schwindt, 2001). Furthermore, reefs may increase the intensity of parasitism, specially by digenean trematodes on $C$. angulatus adults, which are highly parasitized, because they are habitat of intermediate hosts of these parasites (e.g., the gastropods Heleobia australis and H. conexa) (Etchegoin, 1997).

There is no doubt that the preexisting community at the Mar Chiquita Lagoon was strongly modified by the appearance 
intermediarios de esos parásitos (e.g. los gastrópodos Heleobia australis y H. conexa) (Etchegoin, 1997).

Sin duda, la comunidad preexistente en la Laguna Mar Chiquita ha sido fuertemente modificada desde la aparición de F. enigmaticus y una de las principales modificaciones operó a través de los cambios poblacionales de C. angulatus. El impacto de una invasión en una comunidad se relaciona principalmente con la estabilidad y complejidad de ésta. Cuando un organismo constructor de arrecifes como $F$. enigmaticus se establece en un medio ambiente poco diverso como el fondo blando de la Laguna Mar Chiquita, los cambios producidos sobre la comunidad son extremadamente marcados. Los niveles actuales de densidad y biomasa poblacional de $C$. angulatus no podrían haberse esperado sin los refugios provistos por los arrecifes. Dado que el número y la extensión de las invasiones reportadas son cada vez más elevados, los estudios destinados a cuantificar el impacto de especies invasoras que permiten evaluar la magnitud de los cambios producidos son, obviamente, necesarios.

\section{Agradecimientos}

Nuestro mayor agradecimiento a S. Obenat y a E. Schwindt por sus trabajos previos, sus datos y sus comentarios. A E. Spivak, D. Antinuchi, R. Zenuto y M. Kittlein y a dos revisores anónimos por sus muchas sugerencias vertidas sobre el manuscrito. Este trabajo fue financiado por un subsidio otorgado por la Universidad Nacional de Mar del Plata, y por becas otorgadas por CONICET a T. L., y por CONICET y la Fundación Antorchas a C. B.

\section{Referencias}

Anger, K.C., Bas, E.D., Spivak, D., Ismael and Luppi, T. (1994). Hatching rhythms and dispersion of decapod crustacean larvae in a brackish coastal lagoon in Argentina. Helgoländer Meeresuntersuchungen, 48: 445-466.

Bachmann, S. (1999). Feeding tactics of the American oystercatcher (Haematopus palliatus), on Mar Chiquita coastal lagoon, Argentina. Ornitologia Neotropical, 10: 81-84.

Beck, M.W. (1997). A test of the generality of the effects of shelter bottlenecks in four stone crab populations. Ecology, 78: 24872503.

Bianchi, C.N. and Morri, C. (1994). Present-day serpulid reef: their autoecology, biology and distribution, with special reference to Ficopomatus enigmaticus. International Course on polychaete autoecology: evolutionary trends and adaptive significance of life history traits. Ischia, Italy, $20 \mathrm{pp}$.

Carlton, J.T. (1996). Pattern, process, and prediction in marine invasion ecology. Biol. Conservation, 78: 97-106.

Cohen, A.N. and Carlton, T.T. (1996). Nonindigenous aquatic species in a United States estuary: a case study of the biological invasions of the San Fransisco Bay and delta. Report to U.S. Fish and Wildlife Service.

Escalante, A.H. (2001) Alimentación de juveniles y adultos del "pejerrey" Odontesthes bonariensis (Teleostei, Atherinopsdae). In: Iribarne, O. (ed.), Reserva de Biosfera Mar Chiquita: of $F$. enigmaticus, most notably by changes in the population of C. angulatus. The impact of an invasion in a community relates mainly to its stability and complexity. When a reef building organism like $F$. enigmaticus thrives in a little diverse environment such as the soft bottomed coastal Mar Chiquita Lagoon, changes produced in the community are extremely marked. Current densities and biomass levels of $C$. angulatus population would have never take place without the refuge provided by reefs. Given the increasing numbers and extention of invasions reported, studies to quantify the impact of alien species and evaluate the importance of changes are obviously necessary.

\section{Acknowledgments}

We thank S. Obenat and E. Schwindt for their previous works, data and comments. E. Spivak, D. Antinuchi, R. Zenuto and M. Kittlein and two anonymous reviewers for many suggestions on a draft of the manuscript. This work was funded by a grant from Universidad Nacional de Mar del Plata and by fellowship from CONICET (TL), and CONICET and Fundación Antorchas (CB).

English translation by the authors.

Características físicas, biológicas y ecológicas. Editorial Martín, Mar del Plata, Argentina, pp. 207-212.

Etchegoin, J.A. (1997). Sistemas parasitarios presentes en la Albufera Mar Chiquita. Tesis Doctoral, Facultad de Ciencias Exactas y Naturales, Universidad Nacional de Mar del Plata, 244 pp.

Fasano, J.L., Hernández, M.A., Isla, F.I. and Schnack, E.J. (1982). Aspectos evolutivos y ambientales de la laguna Mar Chiquita (Provincia de Buenos Aires, Argentina). Oceanologica Acta, N'SP: 285-292.

Flores, A.A.V. and Negreiros-Fransozo, M.L. (1999). On the population biology of the mottled shore crab Pachygrapsus transversus (Gibbes, 1850) (Brachyura, Grapsidae) in a subtropical area. Bull. Mar. Sci., 65: 59-73.

Fornos, J.J., Forteza, V. and Martinez Taberner, A. (1997). Modern polychaete reefs in Western Mediterranean lagoons: Ficopomatus enigmaticus (Fauvel) in the albufera of Menorca, Balearic Island. Palaeogeography, Paleoclimatol. and Paleoecol., 128: 175-186.

Gavio, A. and Iribarne, O. (1994). Distribución espacial, selección de hábitat y tasa de mortalidad de Cyrtograpsus angulatus en la albúfera Mar Chiquita: la importancia del canibalismo. II Taller sobre cangrejos y cangrejales. Mar del Plata, p. 9.

Gherardi, F. and Cassidy, P.M. (1993). Sabellarian tubes as the housing of the hermit crab Discorsopagurus schmitti. Can. J. Zool., 72: 526-532.

Gore, R.H., Scotto, L.E. and Becker, L.J. (1978). Community composition, stability, and trophic partitioning in decapod crustaceans inhabiting some subtropical sabellariid worm reefs. Studies on decapod Crustacea from the Indian River region of Florida. IV. Bull. Mar.Sci., 28: 221-248.

Gutierrez, J. and Iribarne, O. (1999). Role of Holocene beds of the stout razor clam Tagelus plebeius in structuring present benthic communities. Mar. Ecol. Prog. Ser., 185: 213-228. 
Haines, J.L. and Maurer, D. (1980). Quantitative faunal associates of the serpulid polychaete Hydroides dianthus. Mar. Biol., 56: 4347.

Heck, K.L. and Hambrook, J.A. (1991). Intraspecific interaction and risk of predation for Dyspanopeus sayi (Decapoda: Xanthidae) living on Polychaeta (Filograna implexa, Serpulidae) colonies. P S Z N I Mar. Ecol., 12: 243-250.

Hozborn, N.H. y García-de-la-Rosa, S.B. (2000). Alimentación de juveniles de Corvina rubia (Micropogonias furnieri) en la laguna costera Mar Chiquita (Buenos Aires, Argentina). Frente marítimo, 18: 59-70.

Kneib, R.T., Lee, S.Y. and Kneib, J.P. (1999). Adult-juvenile interactions in the crabs Sesarma (Perisesarma) bedens and $S$. (Holometopus) dehaani (Decapoda: Grapsidae) from intertidal mangrove habitats in Hong Kong. J. Exp. Mar. Biol. Ecol., 234: 255-273.

Luppi, T.A. (1999). La coexistencia de dos especies de cangrejos en el ecosistema del cangrejal: estudio comparativo del asentamiento y el reclutamiento. Tesis Doctoral, Facultad de Ciencias Exactas y Naturales, Universidad Nacional de Mar del Plata. 101 pp.

Luppi, T., Spivak, E. and Anger, K. (2001). Experimental studies of predation and cannibalism in recruits of Chasmagnathus granulata and Cyrtograpsus angulatus (Brachyura: Grapsidae). J. Exp. Mar. Biol. Ecol., 265: 29-48.

Luppi, T., Spivak, E. and Anger, K. (2002a). Postsettlement growth of two estuarine crab species, Chasmagnathus granulata Dana, 1851 and Cyrtograpsus angulatus Dana, 1851 (Crustacea, Decapoda, Grapsidae): laboratory and field investigations. Helgoland Mar. Res., 55: 293-305.

Luppi, T., Spivak, E. and Anger, K. (2002b). Patterns and processes of Chasmagnathus granulata and Cyrtograpsus angulatus (Brachyura: Grapsidae) recruitment in Mar Chiquita Coastal Lagoon, Argentina. Estuar. Coast. Shelf Sci., 55: 287-297.

Mooney, H.A. and Drake, J.A. (1986). Ecology of biological invasion of North America and Hawaii. Springer-Verlag, New York.

Obenat, S. and Pezzani, S. (1989). Ecological studies of Ficopomatus (Mercierella) enigmaticus (Annelidae: Polychaeta) in Mar Chiquita coastal lagoon (Buenos Aires, Argentina). In: Conservation and development: the sustainable use of wetland resources. Third International Wetlands Conference. Editions du Musèum d'Historie Naturelle, Paris. pp. 165-166.

Obenat, S. and Pezzani, S. (1994). Life cycle and population structure of the polychaete Ficopomatus enigmaticus (Serpulidae) in Mar Chiquita Coastal Lagoon, Argentina. Estuaries, 17: 263-270.

Olenin, S. and Leppäkoski, E. (1999). Non-native animals in the Baltic Sea: alteration of benthic habitats in coastal inlets and lagoons. Hydrobiologia, 393: 233-243.

Olivier, S., Escofet, A., Penchaszadeh, P. y Orensanz, J.M. (1972). Estudios ecológicos de la región estuarial de Mar Chiquita (Bs. As., Argentina). II. Relaciones tróficas interespecíficas. An. Soc. Cient. Argentina, 194: 89-104.

Orensanz, J.M. y Estivariz, M.C. (1971). Los anélidos poliquetos de aguas salobres de la Provincia de Buenos Aires. Rev. del Museo de la Plata, XI: 95-112.

Pinheiro, M.A.A., Bertini, G., Fernandez-Góes, L.C. and Fransozo, A. (1997). Decapod crustaceans associated to sand reefs of
Phragmatopoma lapidosa Kimberg, 1867 (Polychaeta, Sabellariidae) at Praia Grande, Ubatuba, SP, Brazil. Nauplius, 5: 77-83.

Reta, R., Martos, P., Perillo, G.M., Piccolo, M.C., y Ferrante, A. (2001). Características hidrográficas del estuario de la laguna Mar Chiquita. In: Iribarne, O. (ed.), Reserva de Biosfera Mar Chiquita: Características físicas, biológicas y ecológicas. Editorial Martín, Mar del Plata, Argentina, pp. 31-52.

Rioja, E. (1943). Estudios anelidiológicos IX. La presencia de la Mercierella enigmatica Fauvel en las costas argentinas. An. Inst. Biol. México, 14: 547-551.

Rivera-Prisco, M.A., García-de-la-Rosa, S.B. and Díaz-de-Astarloa, J.M. (2002). Feeding ecology of flatfish juveniles (Pleuronectiformes) in Mar Chiquita coastal lagoon (Buenos Aires, Argentina). Estuaries, 24: 917-925.

Ruíz, G.M., Carlton, J.T., Grosholtz, E. and Hines, A. (1997). Global invasions of marine and estuarine habitats by non-indigenous species: mechanisms, extent, and consequences. Am. Zool., 37: 621-632.

Ruíz, G.M., Fofonoff, P., Hines, A.H. and Grosholz, E.D. (1999). Nonindigenous species as stressors in estuarine and marine communities: Assessing invasion impacts and interactions. Limnol. Oceanogr., 44: 950-972.

Schwindt, E. (2001). Efectos de una especie exótica formadora de arrecifes Ficopomatus enigmaticus en la laguna costera Mar Chiquita. Tesis Doctoral, Facultad de Ciencias Exactas y Naturales, Universidad Nacional de Mar del Plata. 140 pp.

Schwindt, E. and Iribarne, O. (1998). Reef of Ficopomatus enigmaticus (Polychaeta, Serpulidae) in the Mar Chiquita coastal lagoon, Argentina. Boll. Societ. d'Hist. Nat. Balears, 41: 35-41.

Schwindt, E., Isla, F. and Iribarne, O. (1999). The infilling of a SW Atlantic coastal lagoon induced by an introduced reef-building polychaete, Argentina. 4th LOICZ Open Science Meeting. Argentina.

Spivak, E.D. (1997). Los crustáceos decápodos del atlántico sudoccidental $\left(25^{\circ} 55^{\circ} \mathrm{S}\right)$ : distribución y ciclos de vida. Invest. Mar. Valparaiso, 25: 69-91.

Spivak, E.D. and Sanchez, N. (1992). Prey selection by Larus belcheri atlanticus in Mar Chiquita lagoon, Buenos Aires, Argentina: a possible explanation for its discontinuous distribution. Rev. Chilena Hist. Nat., 65: 209-220.

Spivak, E.D., Anger, K., Luppi, T.A., Bas, C. and Ismael, D. (1994). Distribution and habitat preferences of two grapsid crab species in Mar Chiquita lagoon (Province of Buenos Aires, Argentina). Helgoländer Meeresuntersuchungen, 48: 59-78.

ten Hove, H.A. and van den Hurk, P. (1993). A review of recent and fossil serpulid "reef", actuopalaentology and the "Upper Malm" serpulid limestone in NW Germany. Geology in Mijnbouw, 72: 23-67.

ten Hove, H.A. and Weerdenburg, J.C.A. (1978). A generic revision of the brackish-water serpulid Ficopomatus Southern 1921 (Polychaeta: Serpulidae), incluiding Mercierella Fauvel 1923, Sphaeropomatus Treadwell 1934, Mercierellopsis Rioja 1945 and Neopomatus Pillai 1960. Biol. Bull., 154: 96-120.

Zar, J.H. (1996). Bioestatistical analysis. Third edition. Prentice Hall, Upper Saddle River, New Jersey, 662 pp. 